\title{
OPTIMISATION OF WIDEFIELD FLUORESCENCE FRET SYSTEM FOR STUDYING SEPARATE MOLECULE INTERACTIONS
}

\author{
Laura Hippe, Šimons Svirskis, Modra Murovska, and Mārtiņš Kālis"\# \\ Institute of Microbiology and Virology, Rīga Stradiṇš University, 16 Dzirciema Str., Rīga, LV-1007, LATVIA \\ \# Corresponding author, Martins.Kalis@rsu.Iv \\ Contributed by Modra Murovska
}

\begin{abstract}
The Förster Resonance Energy Transfer (FRET) method has wide application in modern science for studying protein-protein interactions and conformational changes. FRET allows to assess molecular interactions by measuring energy transfer between acceptor and donor fluorophores coupled to the molecule(s) of interest. The method demands high precision in experimental design, experimental settings and correct data interpretation. Therefore, we tested several parameters to estimate FRET measurement accuracy in our Nikon wide-field fluorescence FRET system. The experiments were performed in a HEK-293 cell line transfected with DNA constructs expressing Calcium Release-Activated Channel (CRAC) subunits STIM1 and ORAl1 coupled to donor fluorophore Cyan Fluorescent Protein (CFP) and acceptor fluorophore Yellow Fluorescent Protein (YFP), respectively. Exposure time and approach of data analysis varied throughout experiments in order to optimise FRET data quality. Dependence of FRET $T_{\text {eff }}$ values on measurement quality and donor/acceptor fluorophore ratio in the cells was estimated. We demonstrated that, using the wide-field fluorescence FRET system, minimising the exposure of fluorophores before measurement using neutral density (ND) filters considerably minimises undesirable photo-bleaching of the fluorophores. There was a strong correlation between the CFP/YFP ratio in the cells and the observed FRET level, suggesting that only cells with certain donor/acceptor ratio might be comparable. We also showed impact of FRET measurement quality, defined as accordance of FRET pixels to Gaussian distribution, on FRET artefacts. Knowledge obtained during our experiments may be important for approbating similar wide-field fluorescence FRET systems to study two separate molecule interactions and for understanding the correct setup of the experiments and data interpretation.
\end{abstract}

Key words: Calcium Release-Activated Channel (CRAC), Förster Resonance Energy Transfer (FRET), HEK 293, YFP, CFP.

\section{INTRODUCTION}

The Förster Resonance Energy Transfer (FRET) method for studying interaction of molecules located at distances $10 \mathrm{~nm}$ or less was first described over 50 years ago (Lankiewicz et al., 1997). FRET can be used as a quantitative light microscopy method allowing detection of close molecular interactions in living cells, which are beyond optical light resolution (Sun et al., 2011; Shrestha et al., 2015). It has wide application in modern science in biomedical research and drug discovery when studying protein interaction and conformation changes in cells ( $\mathrm{Li}$ et al., 2006). The principle of FRET is energy transfer between an excited fluorophore (donor) and another closely situated fluorophore (acceptor), which can be excited with emission spectra of the donor fluorophore (Chen et al., 2003). Protein or protein domain proximity can be measured and physical interactions ana- lysed using a fluorophore pair bound to the proteins of interest, e.g., Cyan Fluorescent Protein (CFP) as a donor fluorophore bound to one protein domain and Yellow Fluorescent Protein (YFP) bound to another protein or domain as an acceptor, which can become excited from the emission spectra of the donor (Periasamy et al., 2008).

The FRET method requires precise identification of the correct setup for the experiments, measurements and data interpretation. The so called "cross talk" is a common artefact in FRET, whereby either acceptor can be directly excited from the wavelength used to excite the donor fluorophore or when the donor's emitted light contributes to the readout of the acceptor's emission measurement (Lee et al., 2005). Berney and Danuser (2003), using a glass coverslip-adsorbed fluorophores, found that the donor/acceptor fluorescence intensity ratio $\left(R_{\mathrm{DA}}\right)$ is important for correct FRET 
measurement. $R_{\mathrm{DA}} 1-20$ has been found to give the most accurate FRET $_{\text {eff }}$ values, while for $\mathrm{R}_{\mathrm{DA}} 20$ the efficiency tends to zero and for $R_{D A}$ plain 1 the efficiency reaches a plateau where changes in $\mathrm{R}_{\mathrm{DA}}$ have minor effect on the FRET $_{\text {eff }}$. Moreover, for correct assessment of distance between the acceptor and donor, it is important to take into account the geometric factor $\chi^{2}$, which characterises the orientation of the donor dipole relative to the acceptor dipole (Lakowicz, 1999). In our study, we aimed to assess the de-

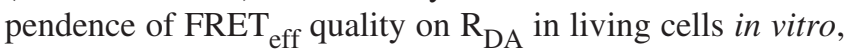
not in situ.

FRET microscopy set-ups for studying two separate molecule interaction are more challenging than in experiments with single molecules labelled with both donor and acceptor fluorophores. Particularly, this may be because of difficulties to reach similar donor and acceptor-labelled molecule ratios in the cells. In this methodological study, we chose the well-characterised Calcium Release-Activated Channel (CRAC), consisting of ORAI1 and STIM1 subunits, as a model for studying two separate molecule FRET settings and output in a widefield fluorescence microscope FRET system. Store-operated calcium channels (SOC), including CRAC, are major pathways for calcium signalling and serve many functions in cells and tissues - gene expression, secretion, and immune response (Berridge et al., 2003). STIM proteins are located in endoplasmic reticulum (ER), being $\mathrm{Ca}^{2+}$ sensors, and, after activation by depletion of $\mathrm{ER} \mathrm{Ca}{ }^{2+}$ store, approach ORAI proteins situated in the plasma membrane and form an ion channel (Gudlur et al., 2013). These ion channels have an important role in human immune cells (T cells, mast cells, NK cells, B cells) (Feske et al., 2010).

The aim of this study was to identify the most optimal conditions for studying two separate molecule interaction using a wide-field dual-detector FRET system and to characterise the quantitative parameters influencing the FRET data quality.

\section{MATERIALS AND METHODS}

DNA constructs. The DNA constructs used in this study were kindly donated by Prof. Christoph Romanin (Johannes Kepler University Linz, Institute of Biophysics, Austria) and had been described previously (Muik et al., 2008). Briefly, the constructs contained the following proteins and coupled fluorophores: 1) STIM1-CFP; 2) CFP-STIM1; 3) YFP-ORAI1; 4) CFP-YFP; 5) CFP; 6) YFP. The plasmid constructs were used for expression of the corresponding proteins, which form CRAC ion channels, as was detected by FRET.

Cell culturing and treatment. HEK 293 cell line was cultured using DMEM with High Glucose supplemented with $10 \%$ FCS, glutamine (2 mM), penicillin, and streptomycin (all from Thermo Scientific, USA). For FRET measurements, cells were seeded on poly-L-lysine-coated (Boster Biological Technology, USA) glass coverslips until 70-90\% confluence and then transfected with plasmid vectors using Lipofectamine LTX with Plus Reagent (Thermo
Scientific, USA). Ten minutes before FRET measurements, cells were washed with PBS and $2 \mathrm{uM}$ thapsigargin (TG) (Alomone Labs, Israel) was applied to induce endoplasmic reticulum calcium depletion, which was necessary for clustering between STIM1 and ORAI1. Control samples were washed only with PBS containing no TG.

Förster Resonance Energy Transfer (FRET) Fluorescence Microscopy. An Eclipse Ti-U wide-field fluorescence microscope (Nikon, Japan) connected to two iXon Ultra EMCCD monochrome cameras (Andor, UK) and a dual port adapter (dichroic, FF509-FDi01-25x36; cyan emission filter, FF01-475/28; yellow emission filter, FF01-550/49-25; Semrock, USA) was used for recording fluorescence images. The wavelengths were selected by filters FF01-427/10-25 (CFP excitation spectrum) and FF01-504/12-25 (YFP excitation spectrum) (Semrock, USA) mounted in a fluorescent light source Lambda DG-4 (Sutter Instrument, USA). NIS Elements software (Nikon, Japan) was used to acquire images, calculate FRET (sensitized emission method) and to control the FRET system. Illumination times of about 200-300 ms were used for acquiring images. Before acquiring images with full fluorescence intensity, the cells were positioned and focused using neutral density (ND) filters 4 and 8 (total density 32) to minimise the fluorophore bleaching. The cells were positioned and focused for 3-5 seconds using ND filters before full intensity light image acquisition was done.

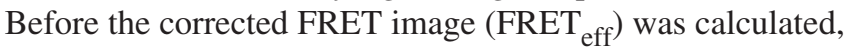
calibration with the single fluorophore control sample images was performed with NIS Elements software to correct calculations for cross-talk and cross-excitation. The FRET $_{\text {eff }}$ was calculated after background subtraction. Exposure time and approach of data analysis varied through experiments in order to optimise FRET data quality.

Statistical analysis. Comparison of means between different groups was performed using mainly one-way ANOVA. Brown-Forsythe and Bartlett's tests were applied to determine whether the collected data had Gaussian distributions. Unequal SD comparison of medians between different groups was performed with the Mann-Whitney test (Fig. 1) or one-way ANOVA on ranks or Kruskal-Wallis test followed by post-hoc analysis (represented in Figs. 2, 4, and 5). The two-stage step-up method of Benjamin, Krieger, and Yekutieli was used in all cases as post-hoc analysis. The Pearson test was used for correlation assessment. For categorical data, the $\chi^{2}$ test was used. Results were expressed as median and \pm IQR (interquartile range) as a dispersion characteristic. A p-value less than $0.05(p<0.05)$ was considered as statistically significant. All the graphs, calculation, and statistical analyses were performed using GraphPad Prism software version 7.0 for Mac (GraphPad Software, San Diego, California, USA).

\section{RESULTS}

In the first experimental setting, we obtained following FRET values: CFP-STIM1 + YFP-ORAI1 w. TG $0.09 \%$ 
[0.035-0.18 IQR] vs. STIM1-CFP + YFP-ORAI1 w. TG $1.69 \%$ [0.39-4.91], $p<0.0001$ (Fig. 1). The FRET sample STIM1-CFP + YFP-ORAI1 w. TG had 60\% $(\mathrm{n}=32)$ of the measured cells with relatively high FRET values (FRET eff $\geq 1.0$ ) comparing to the control CFP-STIM1 + YFP-ORAI1 w. TG which had only $10 \%(\mathrm{n}=3)$ cells in this FRET $_{\text {eff }}$ range ( $p<0.0001$ according to $\chi^{2}$ test).

In the next experimental setting with ND filters (Fig. 2A), initially we observed high background FRET $_{\text {eff }}$ levels and broad distribution in the control sample CFP-STIM1 + YFP-ORAI1 with TG (3.58\% [2.24-7.16]), compared to CFP-STIM1 + YFP-ORAI1 without TG which had FRET eff $_{\text {f }}$ $1.09 \%$ [0.81-1.50], $p<0.0001$. Then, only good quality Gaussian pixel distribution measurements were chosen for analysis, giving the following FRET $_{\text {eff }}$ results: CFP-STIM1 + YFP-ORAI1 without TG 0.885\% [0.66-1.1], CFP-STIM1

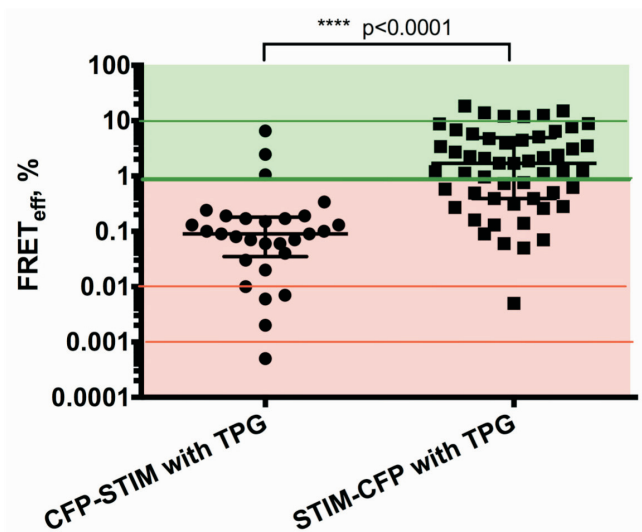

Fig. 1. CFP-STIM1+YFP-ORAI1 with TG (control) and

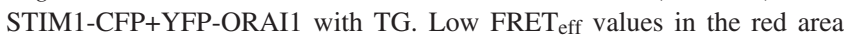
$(0.0001-0.1 \%)$, relatively high FRET values in the green area $(0.1-100 \%)$.

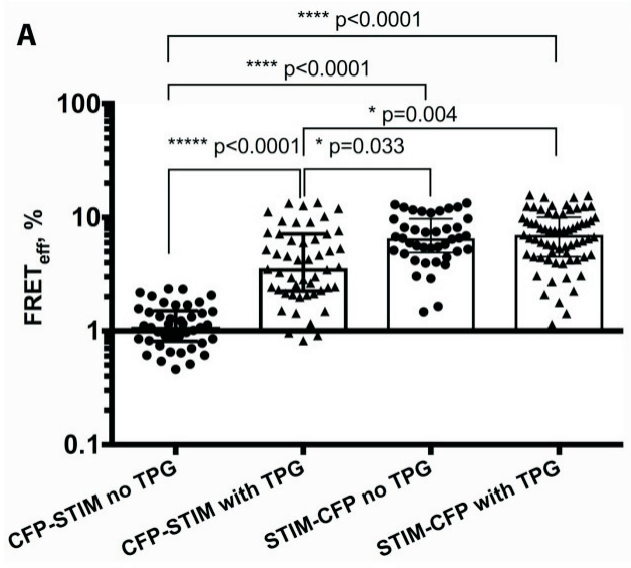

B
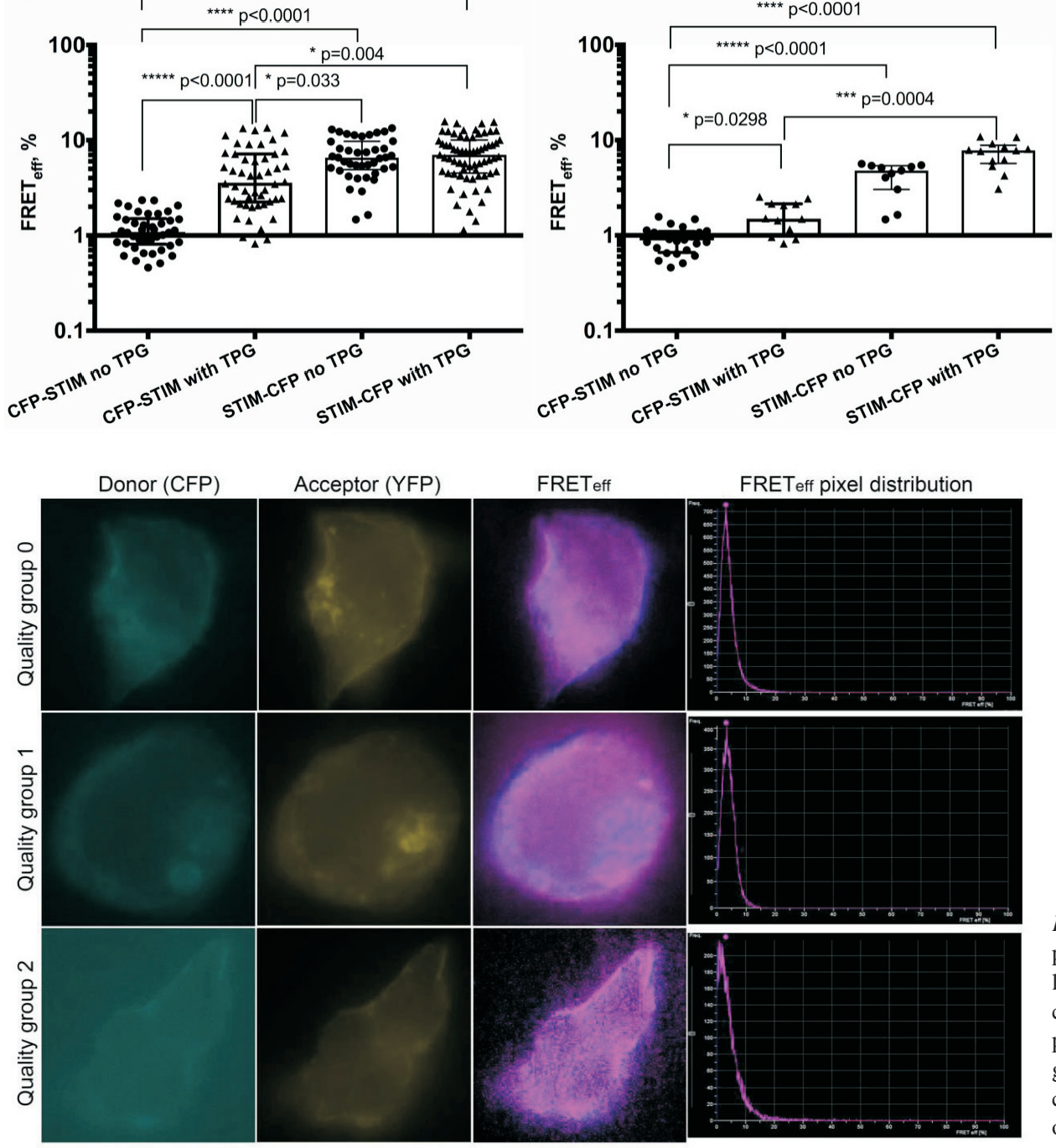

Fig. 2. Mean FRET efficiency (\%) distribution with and without thapsigargin (TG) using ND filters before measurement. Condition descriptions shortened from: CFP-STIM1 + YFP-ORAI1 and STIM1-CFP + YFP-ORAI1 with and without thapsigargin (TG). A, Data before testing for Gaussian distribution. B, Data containing only cells that have a FRET pixel frequency conforming to a Gaussian distribution.

Fig. 3. Quality of the image and FRET eff $_{\text {f }}$ pixel distribution in cells. Purple pixels show low FRET signal, while blue pixels show increased. Quality group 0: a cell with FRET eff $_{\text {ff }}$ pixels that fit Gaussian distribution. Quality

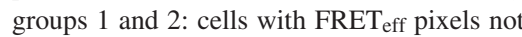
conforming to Gaussian distribution: slightly or strongly, respectively.

+ YFP-ORAI1 with TG 1.5\% [1.01-2.14], STIM1-CFP + YFP-ORAI1 without TG 4.79\% [3.04-5.38] and STIM1CFP + YFP-ORAI1 with TG 7.8\% [5.69-8.83] (Fig. 2B). An example for different quality cell images and the corresponding FRET $_{\text {eff }}$ pixel distribution is illustrated in Figure 3.
Positive and negative controls were also introduced. The median values of positive and negative controls were $35.41 \%$ [31.56-37.19 IQR] $(\mathrm{n}=40)$ and $0.29 \%$ [0.075-0.517] $(\mathrm{n}=72)$, respectively (Fig. 4). The control samples of CFP-STIM1 + YFP-ORAI1 without and with TG, both not able to form CRAC channel and FRET, gave 


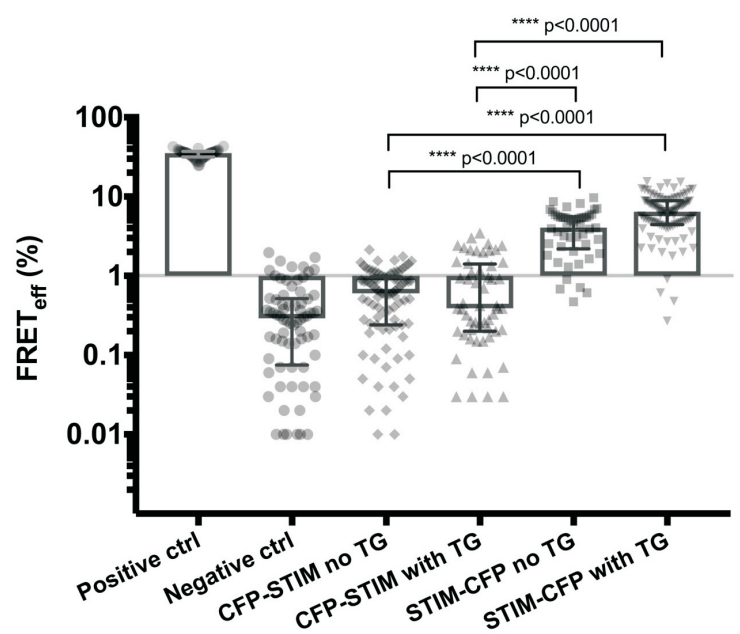

Fig. 4. Distribution of mean FRET $_{\text {eff }}$ values (\%) for positive (CFP-YFP), negative (CFP + YFP) controls, CFP-STIM1 + YFP-ORAI1 and STIM1-CFP + YFP-ORAI1 with and without thapsigargin (TG). Data from 3 independent experiments were pooled. median FRET $_{\text {eff }}$ values of $0.6 \%$ [0.24-0.97 IQR] $(\mathrm{n}=85)$ and $0.39 \%$ [0.2-1.408] $(\mathrm{n}=56)$, respectively (Fig. 4). The FRET-forming STIM1-CFP + YFP-ORAI1 samples showed increased FRET $_{\text {eff }}$ levels in both TG non-stimulated and TG-stimulated samples: 4.07\% [2.185-5.575] $(\mathrm{n}=49)$ and $6.43 \%$ [4.43-8.855] $(\mathrm{n}=97)$, respectively. STIM1-CFP + YFP-ORAI1 samples differ from CFP-STIM1 + YFPORAI1 without TG control sample very significantly ( $p=$ 0.0001, Fig. 4).

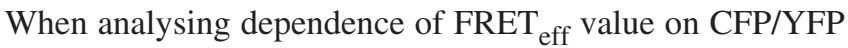
ratio, the following correlation was observed: positive control CFP-YFP, $p=0.0004$ (Fig. 5A), STIM1-CFP + YFPORAI1 + TG, $p=0.021$ (Fig. 5D) and STIM1-CFP + YFPORAI1 - TG, $p=0.014$ (Fig. 5E) demonstrate significant

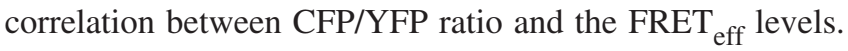
Negative (CFP + YFP, Figure 5B) and CFP-STIM1 + YFP-ORAI1 (Fig. 5C) controls do not express correlation with CFP/YFP ratio.
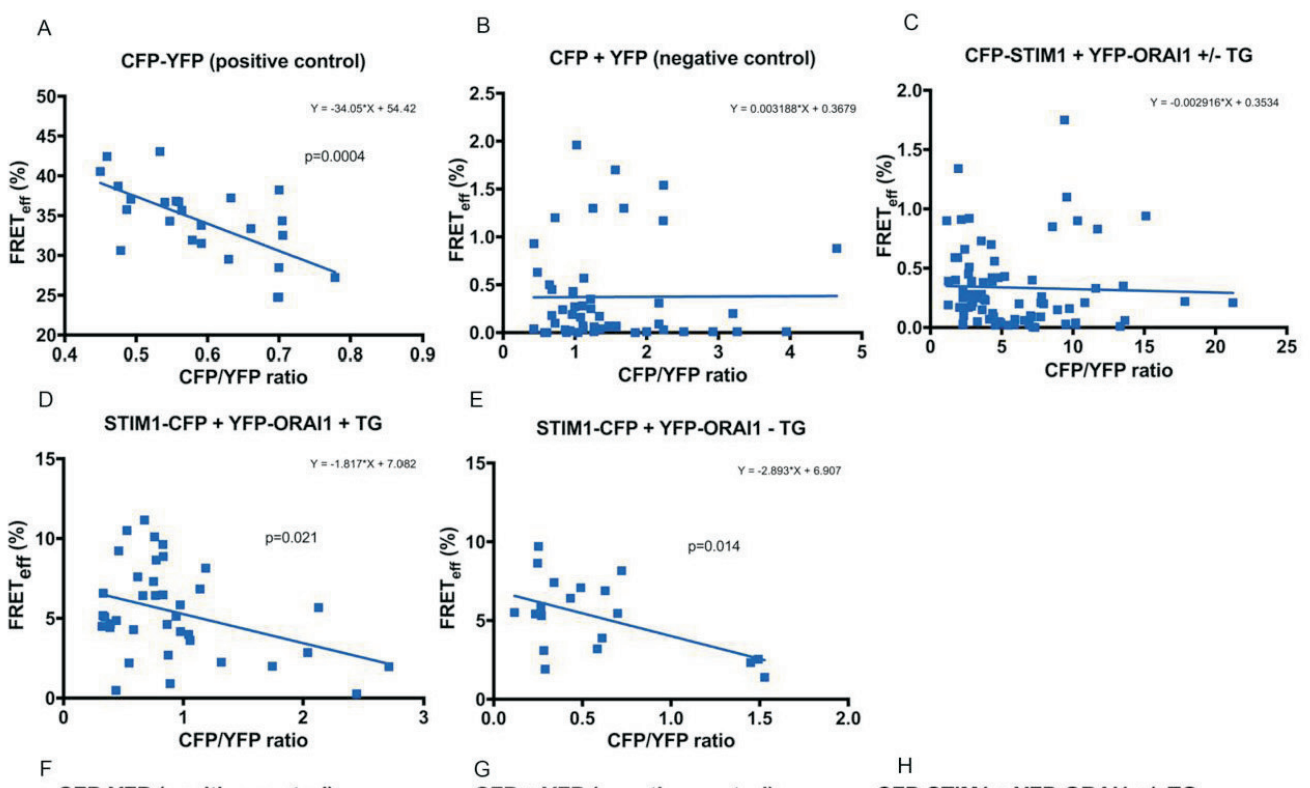

CFP-YFP (positive control)

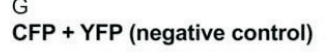

H
CFP-STIM1 + YFP-ORAI1 +/-TG
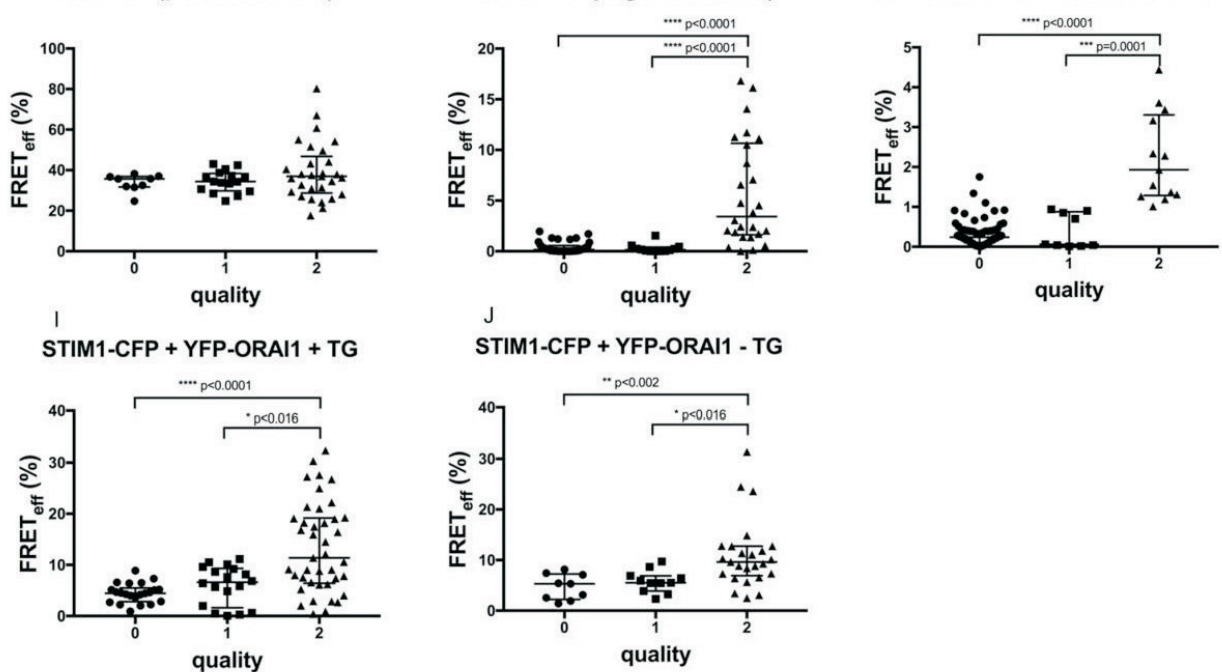

STIM1-CFP + YFP-ORAI1 - TG

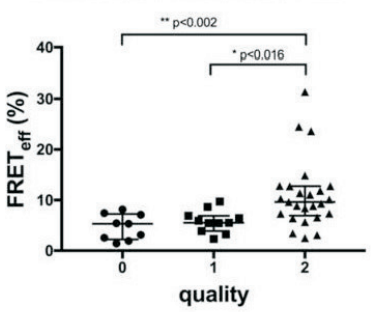

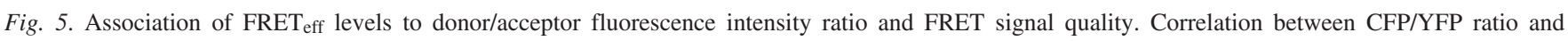

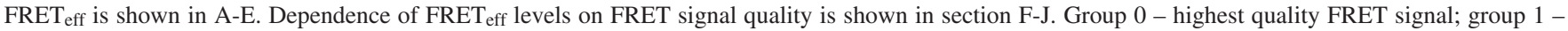
average quality; group 2 - worst quality group. 
We assessed the effect of quality group on FRET $_{\text {eff }}$ artefacts. Positive control showed no significant differences between groups (Fig. 5F). In the negative control (CFP + YFP, Fig. 5G), FRET $_{\text {eff }}$ value in the quality group 2 is $3.43 \%$ [1.625-10.66 IQR] $(\mathrm{n}=26)$ comparing to quality group $1(0.14 \%$ [0.015-0.4], $\mathrm{n}=12, p<0.0001)$ and group $0(0.16 \%$ [0.025-0.565], $\mathrm{n}=37, p<0.0001)$. In the CFP-STIM1 + YFP-ORAI1 control sample (Fig. 5H), median FRET $_{\text {eff }}$ value in quality group 2 is $1.93 \%$ [1.285-3.305 IQR] $(\mathrm{n}=13)$ comparing to practically nega-

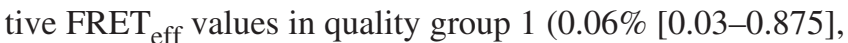
$\mathrm{n}=9, p 0.0001)$ and group $0(0.24 \%$ [0.1-0.4], $\mathrm{n}=71, p<$ 0.0001). In the STIM1-CFP + YFP-ORAI1 + TG sample (Fig. 5I), the median FRET ${ }_{\text {eff }}$ value (11.37\% [6.405-19.17 IQR], $\mathrm{n}=41$ ) in quality group 2 is double comparing to the 0 and 1 group: quality group 1 has median FRET $_{\text {eff }} 6.63 \%$ [1.63-9.323] ( $\mathrm{n}=18, p 0.016)$ and group 1 has median FRET $_{\text {eff }} 4.46 \%$ [2.81-4.485] $(\mathrm{n}=22, p<0.0001)$. Also, in the STIM1-CFP + YFP-ORAI1 sample without TG (Fig. $5 \mathrm{~J})$, the quality group 2 has significantly higher values 9.63\% [6.92-12.75 IQR] $(\mathrm{n}=25)$ comparing to group 1 (5.51\% [3.89-6.89], $\mathrm{n}=11, p 0.016)$ and group $0(5.31 \%$ [2.225-7.245], $\mathrm{n}=9, p<0.002)$.

\section{DISCUSSION}

In order to optimise the FRET protocol for studying two separate molecule interactions in a setting of wide-field fluorescence microscope and two Andor EMCCD cameras, we performed experiments using different experimental approaches. First, we performed an experiment with maximum fluorescence illumination during the whole process. During the next experiments, we used minimised fluorescence illumination intensity during the cell localisation and focusing stage but full intensity during the image capturing. We also introduced data sorting according to the FRET signal quality estimation. Lastly, we analysed the dependence of FRET values on fluorescence intensity ratio of CFP and YFP fluorophores and on data quality. Cells transfected with STIM-CFP + YFP-ORAI1 were used as the sample were FRET is expected, and cells transfected with CFPSTIM + YFP-ORAI1 as a control sample, since the N part of STIM1 is located inside ER lumen and cannot interact with YFP that is coupled to ORAI1. Both cell samples were treated with $2 \mathrm{uM}$ TG to induce ER calcium store depletion, which induces clustering of ER membrane-bound STIM1 and plasmatic membrane-bound ORAI1.

In the first setting (Fig. 1), using full fluorescence intensity during both focusing and measurement, the obtained FRET values were very low, although there were still significant differences between the control and FRET-forming sample. Although the values were low, which can be explained by bleaching of reagents when focusing the cells with full fluorescence intensity before measurement, the FRET sample STIM1-CFP + YFP-ORAI1 w. TG had most cells (60\%) with relatively high FRET $_{\text {eff }}$ while the control sample had only $10 \%$ of the cells in this FRET range.
In the next experimental setting, two neutral density filters, ND4 and ND8 (total effect $32 \times$ less light throughput), were used during positioning and focusing of the cells. The time spent for positioning and focusing the cells was minimised to 3-5 seconds. As a result, we obtained considerably higher FRET $_{\text {eff }}$ values due to more intact fluorophores (Fig. 2A). However, we observed that the FRET $_{\text {eff }}$ values had a broad distribution and CFP-STIM1 + YFP-ORAI1 with TG sample gave high FRET $_{\text {eff }}$ values not expected from a control sample. Therefore, we decided to sort the FRET $_{\text {eff }}$ values according to distribution of FRET $_{\text {eff }}$ pixels. According to Muik et al. (Muik et al., 2008), the frequency distribution of FRET $_{\text {eff }}$ pixels must conform to a Gaussian distribution to be considered good quality measurements. As conformity to Gaussian distribution curve is arbitrary, we provide examples of quality classes in Figure 3.

We noticed that generally cells with good FRET eff $_{\text {Gaussian }}$ distribution had a high contrast image in both channels, with low background and relatively high fluorescence intensity (Fig. 3). After sorting out FRET measurements not conforming to a Gaussian distribution, there was a more clear difference between control and FRET samples (Fig. 2B).

Next, in a set of three independent experiments, we introduced additional plasmids encoding either CFP and YFP linked by a peptide or CFP and YFP expressed as separate proteins (Fig. 4). These served as positive and negative controls, respectively, since linked CFP and YFP always result in a FRET effect, while cells transfected with free-floating CFP and YFP should not result in FRET, since the fluorophores are generally more distant that $10 \mathrm{~nm}$. As a result, we obtained the minimal FRET value as a reference for absence of FRET and the maximal FRET value for constant FRET (Fig. 4). The FRET-forming STIM1-CFP + YFPORAI1 samples showed increased FRET eff $_{\text {levels in both }}$ TG non-stimulated and TG-stimulated samples (Fig. 4). We see that the cells not stimulated with TG also expressed high FRET $_{\text {eff }}$ values. This might have happened due to ER calcium depletion driven by other factors than TG: e.g., receptor signals or biochemical signals (Hawkins et al., 2010).

To understand the factors influencing FRET $_{\text {eff }}$ values, we analysed the dependence of FRET $_{\text {eff }}$ on fluorescence intensity ratio of CFP and YFP fluorophores (Fig. 5, A-E) and on quality of the FRET eff pixel conformity to a Gaussian distribution (Fig. 5, F-J). The quality group 0 included only FRET $_{\text {eff }}$ values made by pixels with Gaussian distribution. Quality group 1 had a relatively poorer Gaussian distribu-

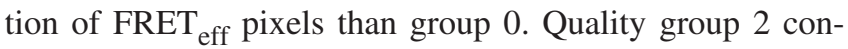
tained FRET $_{\text {eff }}$ pixels showing clearly disturbed Gaussian distribution (see example of group 0,1 and 2 curves in Figure 3 ).

According to the results, there is an obvious dependence of FRET $_{\text {eff }}$ value on CFP/YFP ratio (Fig. 5, A-E). Naturally, we do not see this correlation in negative $(\mathrm{CFP}+\mathrm{YFP}$, Fig. 5B) and CFP-STIM1 + YFP-ORAI1 (Fig. 5C) controls since these samples had only a very low, basal FRET eff $_{\text {sig- }}$ 
nal which can be considered as a negative control for the experiment in both cases.

A higher donor/acceptor fluorophore ratio resulted in lower FRET $_{\text {eff }}$ This observation was consistent with the study of C. Berney and G. Danuser (Berney and Danuser, 2003) that also showed decrease of FRET eff $_{\text {values with higher }}$ $\mathrm{CFP} / Y F P$ ratio in cells. Higher FRET ${ }_{\text {eff }}$ in lower CFP/YFP samples might be explained by higher content of acceptor (YFP) fluorophore, which can thus give higher FRET signal due to higher expression of the acceptor fluorophore itself. The discrepancies due to correlation between donor/acceptor ratio and $\mathrm{FRET}_{\text {eff }}$ may be avoided by filtering the results and using data from only cells expressing a certain donor/acceptor fluorophore ratio.

Regarding FRET $_{\text {eff }}$ values in different quality groups (Fig. $5, \mathrm{~F}-\mathrm{J}$ ), we clearly see an increase in $\mathrm{FRET}_{\text {eff }}$ levels in the worst quality group 2 . In the negative control CFP + YFP, we see dramatic artefact FRET $_{\text {eff }}$ value in the quality group 2 compared to quality group 1 and 0 (Fig. 5G). A similar result was observed in another control sample, CFP-STIM1 + YFP-ORAI1 (Fig. 5H). In STIM1-CFP + YFP-ORAI1 samples with TG (Fig. 5I) and without TG (Fig. 5J), FRET eff $_{\text {in }}$ quality group 2 was twice as high as in group 0 and 1 . We did not observe significant differences between quality group 0 and 1 FRET $_{\text {eff }}$ values, meaning that slight disturbance in the FRET $_{\text {eff }}$ pixel intensity Gaussian distribution curve is tolerable while a poor quality pixel distribution (Fig. 3) causes very significant artefacts by increasing FRET $_{\text {eff }}$ values.

Interestingly, we did not observe significant increase in the positive control sample (CFP-YFP, Fig. 5F). The reason for this may be that the FRET $_{\text {eff }}$ signal had already reached its upper limit.

\section{CONCLUSIONS}

1. Optimal conditions for FRET experiments using a widefield fluorescence microscope require use of ND filters during the preparation of cells for the FRET measurement in order to avoid photo-bleaching.

2. The donor/acceptor fluorescence intensity ratio can considerably influence FRET $_{\text {eff }}$ levels. The fluorophore ratio must be taken into account when interpreting FRET results. The most correct approach would be to choose only cells expressing certain donor/acceptor fluorescence intensity ratios for the analysis.

3. FRET $_{\text {eff }}$ pixel frequencies not conforming to Gaussian distribution cause artefacts of elevated FRET $_{\text {eff }}$ values. However, slight deviation from Gaussian distribution is tolerable.

\section{ACKNOWLEDGEMENTS}

The authors gratefully acknowledge financial support from the EU 7th Framework programme project "Unlocking Infectious diseases research potential at Rīga Stradiňš University" (BALTINFECT), grant agreement No. 316275. We appreciate valuable help and advice from Dr. Rainer Schindl, Johannes Kepler University Linz, Institute of Biophysics, JKU Life Science Center OÖ, Austria.

\section{REFERENCES}

Berney, C., Danuser, G. (2003). FRET or no FRET: A quantitative comparison. Biophys. J., 84, 3992-4010.

Berridge, M. J., Bootman, M. D., Roderick, H. L. (2003). Calcium signalling: Dynamics, homeostasis and remodelling. Nature Rev. Mol. Cell Biol., 4, 517-529.

Chen, Y., Mills, J. D., Periasamy, A. (2003). Protein localization in living cells and tissues using FRET and FLIM. Diff. Res. Biol. Divers., 71, 528-541.

Feske, S., Picard, C., Fischer, A. (2010). Immunodeficiency due to mutations in ORAI1 and STIM1. Clin. Immunol., 135, 169-182.

Gudlur, A., Zhou, Y., Hogan, P.G. (2013). STIM-ORAI interactions that control the CRAC channel. Curr. Topics Membr., 71, 33-58.

Hawkins, B. J., Irrinki, K. M., Mallilankaraman, K., Lien, Y. C., Wang, Y., Bhanumathy, C. D., Subbiah, R., Ritchie, M. F., Soboloff, J., Baba, Y., Kurosaki, T., Joseph, S. K., Gill, D. L., Madesh, M. (2010). S-glutathionylation activates STIM1 and alters mitochondrial homeostasis. J. Cell Biol., 190, 391-405.

Lakowicz, J. R. (1999). Energy transfer. In: Principles of Fluorescence Spectroscopy. Springer, pp. 367-394.

Lankiewicz, L., Malicka, J., Wiczk, W. (1997). Fluorescence resonance energy transfer in studies of inter-chromophoric distances in biomolecules. Acta Biochim. Pol., 44, 477-489.

Lee, N. K., Kapanidis, A. N., Wang, Y., Michalet, X., Mukhopadhyay, J., Ebright, R. H., Weiss, S. (2005). Accurate FRET measurements within single diffusing biomolecules using alternating-laser excitation. Biophys. J., 88, 2939-2953.

Li, I. T., Pham, E., Truong, K. (2006). Protein biosensors based on the principle of fluorescence resonance energy transfer for monitoring cellular dynamics. Biotechnol. Lett., 28, 1971-1982.

Muik, M., Frischauf, I., Derler, I., Fahrner, M., Bergsmann, J., Eder, P., Schindl, R., Hesch, C., Polzinger, B., Fritsch, R., Kahr, H., Madl, J., Gruber, H., Groschner, K., Romanin, C. (2008). Dynamic coupling of the putative coiled-coil domain of ORAI1 with STIM1 mediates ORAI1 channel activation. J. Biol. Chem., 283, 8014-8022.

Periasamy, A., Wallrabe, H., Chen, Y., Barroso, M. (2008). Chapter 22: Quantitation of protein-protein interactions: Confocal FRET microscopy. Meth. Cell. Biol., 89, 569-598.

Shrestha, D., Jenei, A., Nagy, P., Vereb, G., Szollosi, J. (2015). Understanding FRET as a research tool for cellular studies. Int. J. Mol. Sci., 16, 6718-6756.

Sun, Y., Wallrabe, H., Seo, S.A., Periasamy, A. (2011). FRET microscopy in 2010: The legacy of Theodor Forster on the 100th anniversary of his birth. Chemphyschem, 12, 462-474. 


\section{PLAŠĀ LAUKA FLUORESCENCES FRET SISTĒMAS OPTIMIZĀCIJA ATSEVIŠĶU MOLEKULU MIJIEDARBĪBAS PĒTĪJUMIEM}

Ferstera rezonanses enerǵijas pārneses (Förster Resonance Energy Transfer, FRET) metodei ir plašs pielietojums mūsdienu zinātnē proteīnu-proteīnu mijiedarbību un konformācijas izmainu pētījumos. FRET palīdz raksturot molekulārās mijiedarbības, izmērot enerğijas pārnesi starp akceptora un donora fluoroforiem, kas pievienoti pētāmajām molekulām. Metodei nepieciešama ḷoti augsta precizitāte eksperimenta plānošanā un eksperimenta iestatījumos, kā arī pareiza datu interpretācija. Mēs testējām vairākus FRET mērījumu precizitāti nosakošos parametrus Nikon plašā lauka fluorescences FRET sistēmā. Eksperimenti tika veikti ar HEK-293 šūnu līniju, kas transficēta ar DNS konstruktiem CRAC (Calcium Release-Activated Channel) subvienību proteīnu STIM1 (iezīmēts ar CFP (ciānzilais fluorescentais proteīns) fluoroforu) un ORAI1 (iezīmēts ar YFP (dzeltenais fluorescentais proteīns) fluoroforu) ekspresijai. Ekspozīcijas laiks un datu analīzes veids dažādos eksperimentos atšksīrās, lai optimizētu FRET datu kvalitāti. Tika noteikta FRET eff vērtību atkarība no mērījumu kvalitātes un donora/akceptora fluoroforu gaismas intensitātes proporcijas šūnās. Mūsu dati parāda, ka, lietojot plašā lauka fluorescences FRET sistēmu, saīsināta fluoroforu ekspozīcija pirms mērījumu veikšanas, izmantojot neitrālā blīvuma filtrus, būtiski samazina nevēlamo fluoroforu izbalēšanu. Pastāv stipra korelācija starp CFP/YFP proporciju šūnā un novērojamo FRET līmeni, kas nozīmē, ka tikai šūnas ar līdzvērtīgu donora/akceptora fluorofora proporciju var tikt salīdzinātas. Mēs arī parādām FRET artefaktus, kurus rada slikta FRET mērījumu kvalitāte, kas izteikta kā FRET pikseḷu atbilstība normālsadalījumam. Zināšanas, kas iegūtas šajā pētījumā, varētu būt nozīmīgas, lai aprobētu līdzīgas plašā lauka fluorescences FRET sistēmas, kurās tiek pētīta divu atsevišķu molekulu mijiedarbība, un labāk izprastu precīzu eksperimentu veidošanu un datu interpretāciju. 